\title{
Lidi Peeling Machine Technology in Pekan Sawah Village Kecamatan Sei Bingei Kabupaten Langkat
}

\author{
Budi Utomo ${ }^{1^{*}}$,Muhammad Husni ${ }^{2}$ \\ ${ }^{1}$ Faculty of Forestry, Universitas Sumatera Utara, Kampus USU Padang Bulan, Medan \\ 20155, North Sumatra, Indonesia \\ ${ }^{2}$ Faculty of Law, Universitas Sumatera Utara, Kampus USU Padang Bulan, Medan 20155, \\ North Sumatra, Indonesia \\ *email: budiutomo@usu.ac.id
}

\begin{abstract}
Pekan Sawah Village is located in Sei Bingei District, Langkat Regency, North Sumatra Province. This village is $75 \mathrm{~km}$ from the city of Medan, which can be reached using a four-wheeled vehicle in 1.5 hours with the asphalt road conditions that are quite good. The residents of Pekan Sawah Village are generally the Karo tribe, which covers $80 \%$ of the total population. In general, the population is now doing business with oil palm, rubber, and only a small portion of them still maintains land farming businesses such as corn, long beans, etc. The high number of oil palm planters, which reaches $80 \%$ of the population, causes high unemployment in this village. This is because the work to carry out maintenance to harvest is very limited. But on the other hand there is oil palm leaf midrib waste which is a result of the castration process and or the oil palm fruit harvesting process itself. This waste is now made into sticks, which are then sold per kilo to the estimator, which is increasingly expensive and the available stock is very limited, while market demand is high. However, the residents experienced problems in trying to separate the sticks from the leaves. Work is done conventionally one by one so it takes a long time. This results in low productivity of sticks in this area. The entry of the USU Community Services Implementation Team raises new hopes for the community to be able to find solutions that are faced by this community. Complaints about the production of oil palm stick broomsticks were immediately raised by the traditional leaders in Pekan Sawah Village. The USU Community Services Implementation Team immediately formed a problem-solving team. Several lecturers were involved in this activity, including providing education on the correct disposal of palm oil waste for residents. This activity is also assisted by 5 students who have been trained to take action to solve this problem. Now the people of Pekan Sawah Village can increase their lid production using this stick machine.
\end{abstract} Keywords: oil palm, waste, unemployment, sticks, machines.

\section{INTRODUCTION}

O ekan Sawah Village is located in Sei Bingei District, Langkat Regency, North Sumatra Province. This village is $40 \mathrm{~km}$ from the city of Medan which can be reached by using a four-wheeled vehicle in 1.5 hours with the asphalt road conditions that are quite good. Geographically, this village is located on a relatively flat land. There is a stream of Sei Bingei water that comes from the Mount Leuser National Park with a large water discharge, which ensures the availability of water for the rice fields in this area. Therefore, it is not surprising that the government previously built the Namu Sira-Sira Dam to provide water for the rice fields around this area downstream. Because of this, historically this village has been called a rice field week because it is a stretch of rice fields and a rice barn for the Binjai region and its surroundings. However, along with the times there is a shift in agricultural commodities to plantation commodities such as oil palm and rubber. Reflecting on the emergence of oil palm plantations located in the upstream village of this area, the population has flocked to replace the rice commodity into oil palm because it is considered more promising. Now $80 \%$ of the population's agricultural area has shifted to oil palm plantations which are now in their 20s. Only a small portion of the land is retained as paddy field (BPS, 2017).

In this village there are 12 hamlets. The majority of the population is from the Karo tribe, however, several other tribes are found in this village such as the Javanese, Simalungun Batak, 
Mandailing Batak and Nias. As much as $60 \%$ of the population is Christian and the remaining $40 \%$ is Muslim. The village is inhabited by no less than 800 families or more than 3000 people. There are 2 churches, 2 mosques and 1 Islamic boarding school in this village. In addition, there is 1 public elementary school in this village. To take higher education, rural children have to go to school outside the village or to the nearest city, namely Binjai, which is $20 \mathrm{~km}$ (can be reached in 30 minutes).

The work of the villagers who used to farm rice has now shifted to the oil palm commodity. As much as $80 \%$ of agricultural land has been converted to oil palm plantations since 20 years ago and has now entered the production period. Due to the low time needed for gardening activities such as harvesting and maintenance, some residents make use of their free time by raising cows. On the other hand, palm oil leaf waste is very much because the majority of people who cultivate this plant. During harvesting, harvesting workers will remove the oil palm fronds to make it easier to harvest. The vast area of this plant causes this waste to be widely available in this village. This brings potential additional income for the community to make sticks from palm oil leaf waste. So far, the work of making sticks is carried out conventionally by residents by shaving one palm leaf by one so it takes a long time for productivity (Azzamy, 2017).

This community service activity in Pekan Sawah Village aims to solve the problems of the village community in the form of making a broom stick from palm oil leaves. The entry of the Community Services Implementation Team in Pekan Sawah Village brought fresh air to the community because it was like finding a place to ask questions for the community. The community raises all questions regarding their palm oil waste and efforts to overcome it. The availability of palm oil waste such as oil palm leaves is a possible alternative to address community problems. The amount of free time and the high potential for oil palm leaves also have the opportunity to generate additional income in the form of a broom stick made from oil palm leaves. However, the community also complained about the method of making this stick broom.

\section{METHODS}

The Community Services program is implemented in Pekan Sawah Village, Sei Bingei District, Langkat Regency, North Sumatra Province. The activity lasts for 6 months from the start of the activity until the submission of the activity report. Activities are planned to start in June 2020 until completion.

Learning activities are carried out by providing theory which is carried out in such a way that it is easily understood and understood by the community. The use of equipment in the form of an LCD projector is a vital means to be used, so that it will further increase public interest in the topics presented. As for learning activities, it will be carried out through theory and applied activities in the field that will be carried out by the community, students and lecturers at the University of North Sumatra who have competence with the respective fields of activity to be carried out.

Activities undertaken include: Identification of problems. After identifying the problems faced by the target partners, the USU Community Services Team discussed problem-solving techniques taking into account the limitations of cost, time and the effectiveness of the methods used. The problem solving activity was carried out at the original university, namely at USU. This is because USU has sufficient and capable resources. In addition, USU also has workshops and units that have the ability to create the required science and technology products (Almasdi, 2007).

Analysis of problem solving methods. Taking into account the limitations of multi-year Community Services grant assistance that might be obtained from USU's Non-PNBP funds, the Community Services Team conducted an analysis of problem-solving methods. The funds obtained must be able to produce science and technology products that can be directly used to solve the problem of palm oil waste.

Analysis of the availability of raw materials for science and technology products. The Community Services team conducted a market analysis related to the availability of raw materials to produce a 
system of science and technology equipment, such as a 6 HP gasoline engine, iron of various sizes for the manufacture of chopper crushing and separating oil palm leaves from the lid, dynamo and other equipment. In this case, it can be ensured that all the raw materials are sufficiently available in the market and can be used for the completion of this science and technology tool manufacturing work.

Analysis of the ability of the workshop / workshop to make science and technology products. The Community Services team conducts a workshop analysis on the ability and availability of equipment needed for the manufacturing process of science and technology equipment products. If the facilities in the laboratory owned by the Faculty of Engineering are insufficient, the Team will use other workshops / workshops outside USU that are capable of carrying out the work of making this equipment.

Design tools. The design of a tool for making sticks from oil palm leaves is done by describing the tools that will be made in the engineering laboratory. These pictures will then be followed up by making a working system for the shaved stick machine from palm oil leaves after all the materials and equipment are available. The following is an overview of the chopper machine that will be made. Broomstick Maker Tool Products. The tool for making a broom stick is made from a simple machine built in the Engineering Faculty workshop / laboratory. The Community Services Implementation Team will make a tool from a dynamo that is large enough to be used to move the palm leaf separator. This dynamo is driven by electric power which is then connected to a stick separator using a pulley and tire rubber. Then the workers will only need to improve their skills to separate the sticks from palm oil leaves for further making broom sticks.

Implementation of Community Services activities in the target village. The implementation of community services activities in Pekan Sawah Village includes several stages, namely:

a. Learning about equipment working systems and maintenance techniques.

b. Establishment of an organization / group that is responsible for the continuity of maintenance work for the stick draw machine and its installation.

c. Establishment of an organization / group that is responsible for the continuity of maintenance work for the broomstick maker and installation.

Partners' participation in program implementation starts with the Village Head and Village Officials of Pekan Sawah for the arrival and wishes of implementing Community Services by the USU Community Services Team. After receiving the delivery of the intent and arrival of the Community Services Team, the Village Head and his officials welcomed this activity. The Village Head then asked the Team to tour the community. It turned out that the enthusiasm of the residents of Pekan Sawah Village was very high in accepting the planned activities to be carried out by the Community Services Team. The residents provide a place for training, form working groups that will ensure the sustainability of this program.

\section{RESULT AND DISCUSSION}

One of the waste products of oil palm is the leaves, which are the leaves will be removed along with the midribs to make it easier for farmers to harvest the fresh fruit bunches of oil palm. Thus, the fronds at the bottom of the palm oil bunches must be cut and removed to facilitate harvesting of the fruit from the tree. This product has long been a waste for oil palm plantations both in large estates and by community gardens. In one midrib it can contain up to 50-80 leaves that are attached to the sticks attached to the palm leaf midribs. Now these sticks are starting to be sought after by collectors who reportedly can make various products such as broom sticks, asbestos, as well as for other products. In addition, this product is sought after by collectors for the export needs of the Chinese and Indian markets.

The collectors usually come to the villages every week to buy and collect sticks that are ready to sell. Collectors usually require certain requirements for high-quality and high-priced sticks, such as cleanliness and dryness. 
According to Mitri et al. (2018) residents usually clean the sticks from the palm leaves and dry them in the sun for 5-7 days so that they cook dry. These sticks are purchased by collectors at a price of Rp. 3000 to Rp. 3200 per kg. Until now, some of the stick products obtained from the village are still bought by collectors. Unfortunately, consumer needs are not in line with the production of these sticks themselves. The residents make sticks using the conventional method, namely by manually shaving the sticks using a tapping knife or an ordinary knife one by one. This resulted in the production of sticks being very low compared to market demand.

Now with the trend of increasing demand for sticks, almost every house in Pekan Sawah village produces oil palm sticks. The residents complained about this to the USU Community Services Implementing Team about the possibility of a machine for cleaning / shrinking sticks using machines. Based on the residents' complaints as stated in a statement by the village head of Pekan Sawah, Mister Tarigan, the Team conducted an analysis regarding the possibility of making or procuring this stick machine.

The Implementing Team immediately conducted an analysis of the possibility of making this tool at the USU Campus. As a result, the team was able to prepare one unit of palm oil stick drawstring using a modern machine. The process can also be done in large quantities, namely every 30-50 palm leaves for one shaved. Each shavings is also relatively short because it only takes 1-2 minutes, then you get the sticks that are clean and ready to dry in the sun.

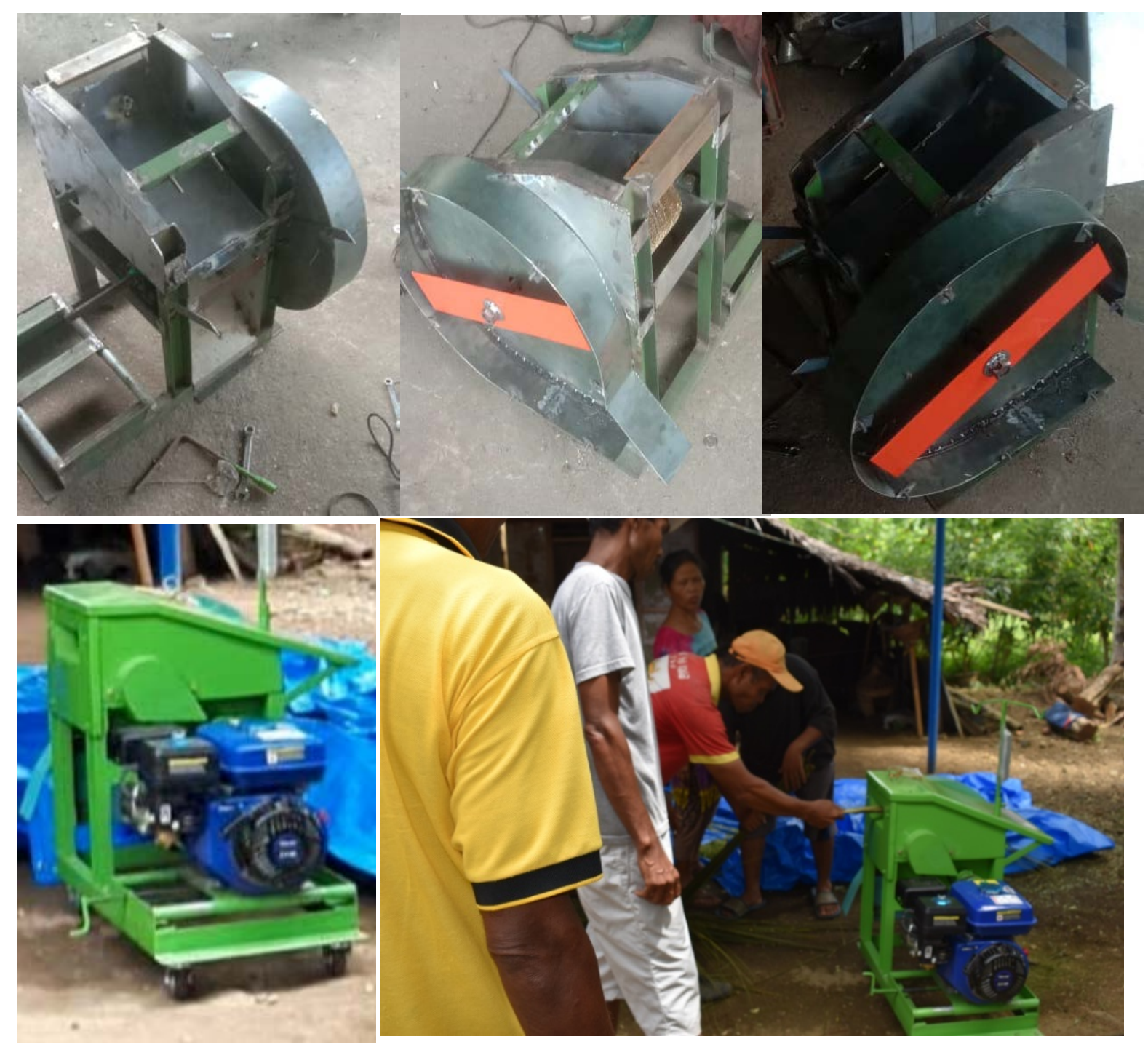


Figure 3.1. The process of making a palm leaf stick shaved machine and the machine used as a shaved machine (above); Testing of shaved machines handed over to community members (below)

The process of making this stick machine takes 1 month because it is related to measuring the mall and other jobs. After the drawstring is finished, the next job is painting and installing the gasoline engine to move the drawstring wheel using cross-wire. This Bross functions as a cleanser for palm oil leaves from its stalks. The machine used this time is a gasoline engine with a power of 5.5 HP. This machine is considered capable based on the calculation that the drive wheel is only used for shaving, not cutting hard parts.

After the machine is finished, the next step is to test the engine. After it was confirmed that all machines functioned according to the wishes of the USU Community Services Implementation Team, the machines were tested first before being handed over to residents in need. After making sure everything runs smoothly and normally, then the machine is handed over to the community for daily use.

Basically, people want this machine to be accepted by them in large enough numbers so that all groups of society can take advantage of this machine. However, given the limited funds, the Team can only provide 1 ready-to-use machine, as well as a prototype for the community. To the village oil palm, the Team stated that the villagers, under the supervision of the village head, could make this tool by imitating the way this donated tool works. With the costs that might be obtained from village funds, it is possible for villages to make this tool in large quantities for community needs.

Now the residents of Pekan Sawah Village are able to carry out the activity of shrinking oil palm sticks quickly. The residents no longer carry out conventional stick-drawn activities, but they only need to come to the farmer groups handed over by the village head to carry out the drawstring activity in a fast way.

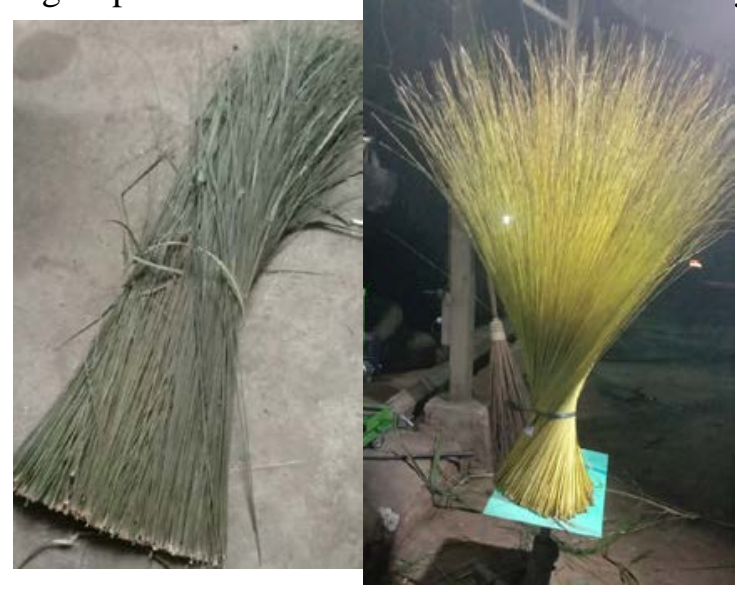

Figure 3.2. Oil palm leaves before processing (top); palm leaves after being processed into sticks using a machine assisted by the USU Community Services Team

\section{CONCLUSION}

From the results of the activities carried out, it was concluded that the creation of a palm leaf shaved machine that was innovative and very useful in accelerating the work of shaving oil palm leaves which produced palm oil sticks was relatively much faster than the conventional method using a knife. The community is very grateful for the assistance provided by the community services Implementation Team from USU.

\section{ACKNOWLEDGMENTS}


Through this article, the author would like to express his gratitude to the University of North Sumatra for the 2020 Non-PNBP Community Service Fund Grant.

\section{REFERENCES}

Almasdi S. 2007, Community Empowerment Model in Efforts to Accelerate Agribusiness-Based Rural Economic Development in Riau Region, DP2M Directorate General of Higher Education, Ministry of National Education, Jakarta.

Azzamy. 2017. General Guidelines for Complete Oil Palm Cultivation. Plantation Cultivation. https://mitalom.com. (Access date April 5, 2020).

[BPS] Central Bureau of Statistics. 2017. Sei Bingei District in Figures in 2017. Annual Publication Series of BPS Langkat Regency, North Sumatra Province.

Dianto F, Efendi D, and Wachjar A. 2017. Management of Oil Palm Harvesting (Elaeis guineensis Jacq.) Pelantaran Agro Estate, East Waringin City, Central Kalimantan. Bul. Agrohorti 5 (3): 410 - 417 (2017).

Mitri I, Syahza A, Asmit B, Suarman, Riadi RM, Bakce, Tampubulon D. 2018. Increasing Community Income through the Utilization of Palm Oil Stick Waste in Sepahat Village, Bengkalis Regency. Proceedings of the Seminar on Community Service Results. ISBN: 978-602-73114-5-9.

[LPPM USU] Community Service Institution. 2019. Program activities. http://usu.ac.id/id/ (accessed April 05, 2020).

Sempurna GA. 2018. How to Cultivate Oil Palm to Harvest, Evidently the Harvest is Abundant. https://gdmorganic.com. (Access date April 5, 2020). 